\title{
TRANSFORMING LIBRARIES AS A PROFIT-MAKING ORGANIZATION TO IMPROVE SERVICE PERFORMANCE
}

Preliminary communication

UDK: 02:005.1

JEL classification: I25, L30, O36, Z19

DOI: 10.17818/DIEM/2022/1.7

Accepted for publishing: July 8, 2021

\begin{abstract}
Libraries are non-profit service-oriented organizations engaged in satisfying the patrons' needs by providing them with whatever they seek from the library, i.e., Books, Journals, Magazines, CDs/DVDs, and Online Resources. However, the libraries must face hardships regarding funds which create difficulties in maintaining the libraries and providing better library services. Its high time libraries should become self-dependent rather than depending upon the funds provided by the parental organization. The funds that the parental organization allocates are minimal and do not cover every area pertaining to the library. Purpose: The purpose of the paper is to conceptualize the transformation of libraries into profit-making organizations to provide improved library services. Results: To make libraries a profitmaking organization, librarians should go unconventional by making some amends in the library policy like charging money in exchange for some services which were earlier not provided by the libraries, i.e. (1) Rental of equipment: Renting the items like Computers, CD/DVDs, Cassette, among others, can provide some rents. (2) Advertisement: Libraries can charge advertisement costs by promoting books written by authors. (3) Selling the weeding out items. (4) Translation. (5) Reproduction Cost. (6) Service charge on-demand services. (7) Inter-Library Services. (8). Membership Schemes. (9) Book Reservation. (10) Training. The charges incurred from the above services are implemented to make the library a better place by providing better resources and better services. Conclusion: Libraries are meant to be nonprofit organizations and must provide services free of cost to the patrons, but the library's primary goal is also to keep the users' satisfaction into consideration. To keep the users satisfied, libraries must keep implementing new policies and procedures to keep them going head on head with time.
\end{abstract}

Keywords: Library Services, Library Resources, Library Funds

\section{INTRODUCTION}

Libraries are a very important part of an institute which is related to research and education. Libraries play a prominent role in every field of education whether it is Science, Arts or Commerce, 
and even in special subjects like Engineering, Medical, Law or Media. Libraries provide resources and required support to the users of their parental organization. There are different types of libraries (figure: 1) i.e., Academic Libraries (School Library, College library and University Library), Public Libraries (District Library, State Library, and so on), Special Libraries (Medical Library, Law Library, Media Library). Academic libraries encourage the user mainly from the common public who want to constantly upgrade their knowledge helping in the development of a local community. On one hand, users need the resources to improve their knowledge base but on the other hand libraries are suffering a lot in terms of funding. It has been seen that funding of libraries is always on the lower side. So, it's better if libraries make themselves self-sufficient by doing some amends into their system, rather than waiting for their parental organization to make them selfindependent.

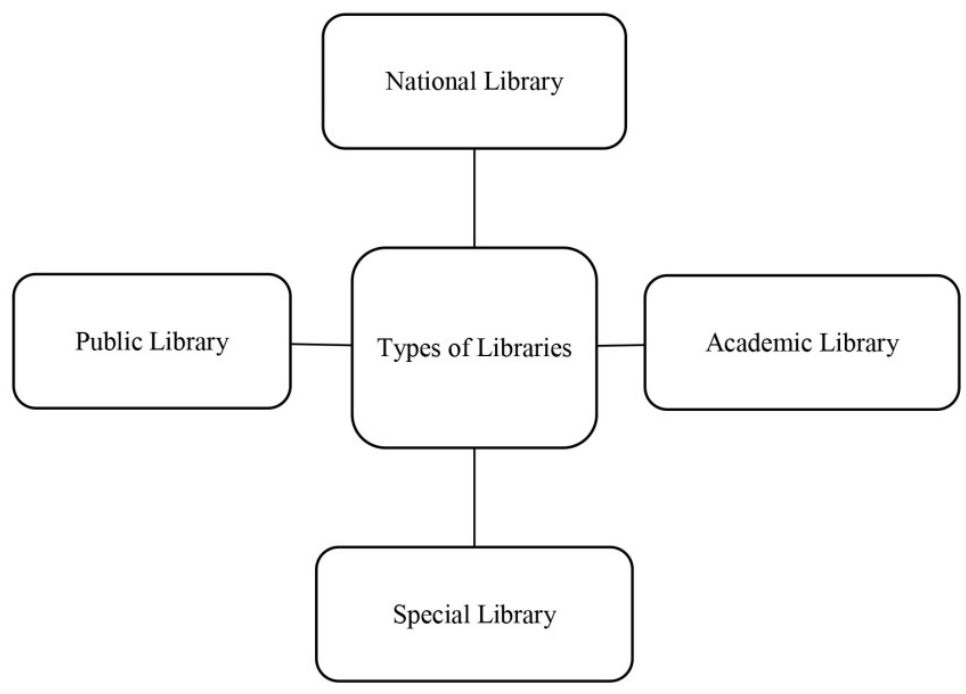

Figure 1 Types of Libraries

\section{OBJECTIVES}

Following are the objectives of the study:

- To conceptualize the evolution of a library into a self-sufficient organization, so that it can perform better having a surplus of funds.

- To conceptualize the transformation of libraries into profit making organizations by providing the services to improve its performance.

\section{LITERATURE REVIEW}

It is difficult to find literature discussing the approach in making the libraries earn by providing their in-house services since libraries are non-profit service-oriented organisations. Lorenzen (2010) discussed the problem of funds in academic libraries of America due to recession which have increased the cost of materials. Acquisition was a big issue and library staff used to be employed at a minimum wage. Most of the larger libraries of America employed one or more fundraisers known as academic library officers who tend to seek external funds. Beaubien and Lynch (1991) discussed in their 80-page report about the alternative sources of revenue for academic libraries by distributing questionnaires in more than 800 academic libraries and suggested that funds can be collected from fines, services, events, rents, among others. Roberts (2003) studied the financial management of libraries in context of past, present and future. The main emphasis of that study was focus in relation to the growth of information service management and the impact of Information Communication Technology in finance of a Library. Tweed (1984) reported a study on 
special libraries and information centres with the objective to suggest a better solution to convert libraries into a profit centre and concluded by mentioning that a proper business strategy should be prepared by answering the following questions: 1) What is the business? 2) What are their clients? 3) What do they expect, and 4) How can an organization give them more than they expect? Warnaby and Finny (2005) considers the marketing-oriented approach which was adopted by the British Library to be implemented for the sustainable development of the libraries. Blery, Katselt and Tsara (2010) examined the marketing policies employed by the World Wide Fund for Nature. The finding suggests that the organization uses a variety of media for promotion such as direct email, newsletters, magazines and internet to attract donors for the survival and protection of animals which are threatened to extinction.

\section{LIBRARY AND FINANCE}

Libraries are non-profit organizations, and they are not related to any revenue earning mechanism. They are usually a component of institutions or academic bodies. Libraries have a special obligation to manage their funds judiciously as finance is an instrument of control and evaluation. Those were the obligations libraries were following but the main motto of the library is to provide better services and adequate resources to the users. The funds provided to the libraries as grants are not sufficient to improve their current performance. So, the libraries are finding new ways to fit in the dynamic world. Making libraries as a profit-making institution is also a new idea for its own benefit.

\subsection{Sources of funds}

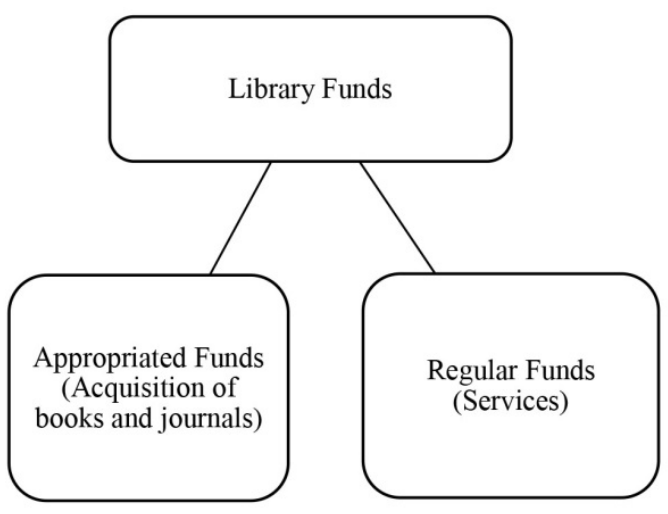

Figure 2 Types of Library Funds

There are two types of funds i) Appropriated funds; which can be used for the acquisition of books and journals ii) Regular Funds; which can be used for the smooth running of the library in providing its services. Different types of libraries receive funds from different sources, though some sources are for all of them, such as government grants. The greatest percentages of operating funds increasingly come from public funds raised through taxes. Funds are required on a continuing basis (paternalistic nature of library) and a judicial estimation of funds required must be done well in advance. Sources of funds can be classified as follows:

Regular grants from parent body (public fund raised through taxes)

Ad hoc grants from other departments/institutions (public fund)

Grants from endowments and charitable institutions

Fines and miscellaneous sources 


\subsection{Different source of funds for different types of libraries}

Table 1 Sources of funds for different libraries

\begin{tabular}{|c|c|c|c|}
\hline \multicolumn{2}{|c|}{ Types of Libraries } & \multicolumn{2}{|c|}{ Source of Funds } \\
\hline \multirow{10}{*}{$\begin{array}{l}\text { 1. Academic } \\
\text { Libraries }\end{array}$} & \multirow{3}{*}{ i) University Libraries } & a) & Parental Organization (University) \\
\hline & & b) & University Grant Commission (UGC) \\
\hline & & c) & State Government. \\
\hline & & & Operating College Fund \\
\hline & \multirow{2}{*}{ ii) College Libraries } & b) & Grants, individual gifts, and endowments \\
\hline & & c) & University Grant Commission (UGC) \\
\hline & \multirow{4}{*}{ iii) School Libraries } & a) & Students Fees \\
\hline & & b) & Contribution from the management \\
\hline & & & Contribution from the government or local body \\
\hline & & & Gifts and Grants \\
\hline \multirow{3}{*}{\multicolumn{2}{|c|}{ 2. Public Libraries }} & & Subscriptions \\
\hline & & b) & Library cess \\
\hline & & c) & Grants from the government and endowments \\
\hline \multirow{2}{*}{\multicolumn{2}{|c|}{ 3. Special Libraries }} & a) & Parental Organization \\
\hline & & b) & Ad hoc grants from governmental agencies obtained for specific purposes \\
\hline
\end{tabular}

\section{METHODOLOGY}

The study is conceptual based on a qualitative paradigm with the main motive was to develop a concept based on the conversion of libraries into a profit-making organization. The idea behind the research is absolutely dedicated to the acknowledgement of the evolution of libraries into a profitmaking organisation from a theoretic perspective. The study provides an interesting platform to bridge theories and present circumstances through research to provide an insight into the ongoing dynamics of a library and how it can be transformed for further betterment. Data sources were mainly confined to Secondary information and obtained from previous literature review, newspaper articles and magazines.

\section{SUGGESTIONS ON GENERATING EXTERNAL REVENUE}

An additional funding will enable libraries to improve their business through improving their services. It is specially seen in India that libraries are going through hardship in terms of funds. Whenever a librarian wants to make some improvement, he always has to think about the limited funds available. Hence, the quality of libraries is degrading day by date. So, it is high time to get out of the box and make some changes in library policy. It's time that we go unconventional and make some profit by providing some extra services. The earnings from those services can be a source for acquiring more documents and providing more services. Following are the ways through which a library can generate external revenue:

\subsection{Fines and penalties}

Libraries make most of their income from membership fees. Every library imposes fines, but the only difference is that the fine has to be submitted to the finance section of the parental organization. Libraries don't get any opportunity to utilize fines in developmental work of a library. On other hand some libraries impose a minimum amount of fine which doesn't do any benefit to the library and users keep committing the same mistakes again. So, in this context, it can be suggested that the collection of fines should be kept in the library for the work development of a library, and they should charge a fine slightly higher than the normal. Libraries can impose fines and penalties on the following: 


\author{
Late return of a book \\ Breaking library rules i.e., talking loudly, using cell phones, eating inside the library etc. \\ Missing Books and reader's card \\ Replacing Books
}

\title{
6.2. Reprography
}

Every user coming to the library using physical books or online resources might always come across something important to make a copy of it for future use. Library staff should take care whether the item is copyright free or not. Once it is confirmed that the item a user is looking for is free of copyright then they can allow the user to take a copy of it by reprography process (Photocopying and Printouts). So, the library can charge an amount for the reprography.

\subsection{Membership charge}

Joining a library for the first time demands completion of formalities like filling up the membership form providing all their details i.e., name, address, contact number, email id, photograph. So, libraries can charge a minimum amount of money for providing their services for a stipulated time.

\subsection{Interlibrary loan}

Libraries under consortium or associations can enjoy the benefit of inter library loan facility through which a member library can borrow any items from the other member libraries. It seems quite impossible for a library to have all the books in the world and in India with limited funds it's quite evident that at some point of time libraries will upset their users due to unavailability of a certain book. In that case the libraries under any association can request a member library to borrow a book on behalf of their user. By satisfying the needs of a user a library can charge for the service.

\subsection{Loan on electronic resources (CD/DVDs)}

Usually, electronic resources like CD and DVDs cannot be loaned to the users due to their fragile nature but when a user insists on issuing the CD/DVD offering valid reasons, then libraries can rent it out for a certain amount.

\subsection{Reservations}

Books are procured in a bulk like a certain book on Research Methodology will be bought by a library in 100 numbers of copies. Sometimes a scenario arises that all the 100 books are already issued to the 100 users. If the $101^{\text {th }}$ user comes to the library to issue the book, then he might be asked by the librarian to reserve the book. Whenever the first copy of a book returns to the library, then the user who has reserved the book will be informed. So, libraries can charge for the service of book reservation.

\subsection{Training}

Libraries can provide training to the users on certain areas and ask the users to pay for those concerned services. Training is provided in the following areas:

Training on use of online resources 
Training on conducting a conference.

Training on plagiarism check

Training on use of Information Communication Technology

\subsection{Selling of weeding out books}

Weeding out of library books is a common practice of libraries. The books which are least used, torn out, out of syllabus etc. are usually weeded out. Those books are usually donated or gifted; but instead of gifting or donating the books libraries can sell them through online platforms like amazon where used books are brought by the interested readers.

\subsection{Exhibition hire}

Public libraries have been established for the development and upliftment of the local community where libraries also support them by promoting it. So, for that purpose public libraries consist of large halls where cultural programs are possible to organize. Academic libraries also consist of large halls for the purpose of holding conferences and seminars. Those halls can be rented to the interested parties for the purpose of conducting exhibitions or third-party conferences.

\subsection{Rental of equipment}

Surplus items like computers, cassette players, software packages, typewriters, microscopes etc. can be rented out to the interested persons and out of which libraries can earn so much extra money. It's better to rent the unused items rather than keeping them idle in the library.

\subsection{Advertising}

Library is the place where readers come to read. There is no other place where a large number of readers could be found. It is an add-on the library can use for their own profit by promoting books or the authors and charging the advertising cost.

\section{CONCLUSION}

Libraries have a wider user base, access to information and technological support in education, and a host of well-trained staff. An intricate management of the expertise of a library in providing services along with a profit motive can go a long way in gathering funds for developmental work within the library. In order to make the library a self-sufficient organization in terms of funds they must go unconventional. A shift in library management is important to reap huge dividends. It would also ensure reinforcing the position of a library in the eyes of the common public, because increase in funds will bring with it enormous multiplication of library functions making it an important economic organisation in our society.

The tag of non-profit organization is a curse to libraries in today's context, owing to which there is always scarcity of funds causing developmental lag within the library. Transforming some of its policies towards profit making can make the library adopt a more professional approach and increase its credibility towards its users. Development of a library also indicates the different ways it can identify itself with the changing face of the society and its occupants. Library dynamics need to constantly evolve depending on the nature of the society, whichever it represents in order to engage the changing nature and mood of the users, and for which the ultimate solution is greater funds for continuous improvement. 


\section{REFERENCES}

Beaubien, A., \& Lynch, M. (1991). Alternative sources of revenue in academic libraries. ACRL College \& Research Libraries News, 52, 573-576. https://doi.org/10.5860/crln.52.9.573

Blery, E. K., Katseli , E., \& Tsara, N. (2010). Marketing for a non-profit organization. International Review on Public and Nonprofit Marketing, 7. https://doi.org/10.1007/s12208-010-0049-2

Brittingham, B. E., \& Pezzullo, T. R. (1990). The campus green: Fund raising in higher education. Washington, DC: School of Education and Human Development, The George Washington University.

Cummings, A. R. et al. (1992). University libraries and scholarly communication: A study prepared for the Andm W Mellon Foundation. Washington DC: Association of Research Libraries.

Carrigan, D. P. (1988). The political economy of the academic library. College \& Research Libraries, 49(4), 325331. https://doi.org/10.5860/crl_49_04_325

Cervone, F. (2005). Library development: A long-term strategy for library funding. Library Administration \& Management, 19(1), 7-15.

Clark, C. K. (1991). Donor and donor relations. In B. Dewey (Ed.), Raising money for academic and research libraries.New York: Neal Schuman Publishers.

Cook, W. B., \& Lasher, W. F. (1996). Towards a theory of fund raising in higher education. The Review of Higher Education, 20(1), 33-51. https://doi.org/10.1353/rhe.1996.0002

Cutlip, S. M. (1965). Fund raising in the United States: Its role in America's philanthropy. New Brunswick: Rutgers University Press.

Davis, M. (1985). Corporate philanthropy and libraries: Will the private sector respond to federal cutbacks? Public Library Quarterly, 6(2), 15-26. https://doi.org/10.1300/J118v06n02_03

De Prospo, E. R., Altman, E., \& Beasley, K. E. (1973). Performance measures for public libraries. Chicago: Public Libraries Association.

Doran, B. (1990). Fund raising for libraries: a case study. Health Information and Libraries Journal, 7, 1-7. https://doi.org/10.1046/j.1365-2532.1990.710001.x

Dolibois, J. E. (1977). Alumni affairs. In A.S. Knowles (Ed.), International encyclopedia of higher education. 2, $320-325$.

Elliott, D. (2006). The kindness of strangers: Philanthropy and higher education. Lanham, MD: Rowman \& Littlefield Publishers.

Ezzell, J. R. (1989). From the Cayman Islands to Washington: Development in academic libraries. North Carolina Libraries, 47(Spring), 38-42. https://doi.org/10.3776/ncl.v47i1.368

Fitzgerald, B. K. (2004). Missed opportunities: Has college opportunity fallen victim to policy drift? Change, 36(4), 10-19. https://doi.org/10.1080/00091380409604972

Geiger, R. L. (1993). Research and relevant knowledge: American research universities since World War II. New York: Oxford University Press.

Gerding, S. (2005). Innovative fund-raising opportunities for your library. Public Libraries, 44(4), p. $212-214$.

Grub, W. N., \& Lazerson, M. (2005). Vocationalism in higher education: The triumph of the education gospel. The Journal of Higher Education, 76(1), 1-25. https://doi.org/10.1353/jhe.2005.0007

Gurin, M. G., \& Til, J. V. (1990). Understanding philanthropy: Fund raising in perspective. In D. F. Burlingame (Ed.), Library development: A future imperative (pp. 3-14). New York: Haworth Press. https://doi.org/10.1300/J111v12n04_02

Lorenzen, M. (2010). Fund Raising for Academic Libraries: What Works, What Doesn't. Library Philosophy and Practice, 1-22.

Roberts, S. (2003). Financial Management of Libraries: Past Trends and Future Prospects. Library Trends, 51, 462-493.

Tweed, S. (1984). The Library as a Profit Center. Special Libraries, 75, 270-274.

Warnaby, G., \& Finney, J. (2005). Creating customer value in the not-for-profit sector: a case study of the British Library. Journal of Philanthropy and Marketing, 10: 183-195. https://doi.org/10.1002/nvsm.18 